\title{
LUTHER OOR DIE DOOP
}

C F A Borchardt

\section{Inleiding}

Oor Luther se opvatting oor die doop is reeds baie geskrywe. " In hierdie artikel wil ek hoofsaaklik uitgaan van Luther se gedagtes soos te vind in sy geskrif $D e$ captivitate Babylonica ecclesiae prae/udium (Die Babiloniese gevangenskap van die kerk), veral omdat sy manier van redeneer so fassinerend is. Daar is bepaalde beklemtonings wat ook vandag nog vir ons van belang is byvoorbeeld dat die Christen steeds elke dag moet lewe uit sy doop.

Luther was 'n man wat die Bybel opnuut ontdek het. Dit was die rigsnoer in sy lewe en die titel wat hy die graagste wou gedra het, was dat hy bekend sou staan as "Doktor van die Heilige Skrif". 2) Sy groot stryd met sy teenstanders was om die gesag van die Skrif weer as soewerein erken te kry. Nie die woorde van die erkende kerkvaders - van Augustinus tot Tomas van Aquino - was vir hom beslissend nie, maar die Woord van God wat bo konsilies en pouslike uitsprake gestaan het. ${ }^{3)}$ Reeds in sy Psalmkommentaar (Dictata super Psalterium 1513-15) het Luther teenoor die gangbare opinie van sy tyd, beklemtoon dat die Evangelie of Woord van God en nie die sakramente nie, gesien moes word as dié genademiddel in die kerk."

Sy vyf en negentig stellinge was 'n protes teen 'n wanpraktyk in die kerk en in sy verhoor voor Cajetanus en veral in sy debat met Johannes Eck het sy gedagtes vaster vorm gekry. In sy sogenaamde groot reformatoriese geskrifte in 1520 kom sy ryp opvatting na vore. Reeds in sy geskrif Aan die Christelike adel het hy die gedagte beklemtoon van die algemene prieterskap van die gelowiges. In sy Babiloniese gevangenskap van die kerk het hy egter die penwortel van die Rooms Katolisisme afgesny, te wete hul sakramentele stelsel waardeur Rome die lewe van elke gemeentelid van geboorte tot sy dood beheer het. ${ }^{51}$

Die direkte aanleiding tot die skrywe van die Babiloniese gevangenskap van die kerk was twee aanvalle van die Leipzigse Romanis Alveld en die Italiaanse Dominikaan Isidoro Isolani. Luther het hulle geskrifte nie 'n uitvoerige weerlegging waardig geag nie. Hy het egter wel geoordeel dat hy kortliks wou antwoord op die vraagstuk wat Alveld na vore gebring het, naamlik of daar Bybelse gronde was vir die gebruik om die gemeentelede by die nagmaal van die beker te weerhou. Hierby wou hy sommer die vraagstuk van die sakramente in die algemeen behandel en dit het dan tot gevolg gehad die verskyning van die Babiloniese gevangenskap van die kerk. ${ }^{6}$ )

Luther het reeds teen die einde van 1519 'n preek oor die doop gepubliseer naamlik Eyn Sermon von dem heyligen hochwirdigen Sacrament der Taufe. Dit was in die vorm van twintig stellinge. Vanselfsprekend sal ons hieronder sy gedagtes in die preek vergelyk met sy opvatting in die Babiloniese gevangenskap. Zur Mühlen meen dat in sy Sermon alle elemente van sy nuwe 
doopleer reeds aanwesig is. Feit is dat Luther in sy Sermon sy standpunt baie kort stel en in die Babiloniese gevangenskap uitvoerig uitwerk soos ons later sal sien. Zur Mühlen meen ook dat Luther in sy Sermon nog sterk aan Augustinus georiënteer was en praat van 'teken, betekenis en geloof' terwyl hy in die Babiloniese gevangenskap die saak behandel vanuit die verhouding 'belofte en geloof'."'

\section{Die gevangenskap van die sakramente}

Die naam van die geskrif Babiloniese gevangenskap is so gekies omdat volgens Luther die sakramente deur die Roomse kurie in ' $n$ jammerlike gevangenskap gevoer is en die kerk van al sy vryheid beroof is. ${ }^{8)}$ Elders waar Luther oor die geweldige betekenis van die doop handel, betreur hy dit dat ons heerlike vryheid en insig in die doop in gevangenskap verkeer en dat dit alles te wyte is alleen aan die tirannie van die Roomse pous. ${ }^{\text {" }}$ Miskien is hierdie laaste kritiek ' $n$ bietjie skerp omdat ons vandag ook nie so uit ons doop lewe soos wat Luther dit sou wou hê nie en dit is natuurlik nie aan die pous te wyte nie. Aan die ander kant is dit ook waar dat die hele Roomse sakramentsleer op 'n dwaalspoor beland het. Elders wanneer Luther al die wanopvattinge aan die kaak stel, verklaar hy dat hy gedwing is om oor die gevangenskap van die kerk te skrywe omdat die eerbiedwaardige testament van God tot slawerny van die mees goddelose gewinsug gedwing is deur die menings en tradisies van goddelose mense wat die Woord van God ter syde stel en die bedenksels van hul hart vir ons voorhou en die wêreld aldus verlei. ${ }^{10}$ ) Rome neem die ware vryheid van die kerk nie slegs gevange nie maar rig dit heeltemal te gronde selfs meer as die Turke. Die apostel waarsku daarteen as hy sê: moenie slawe van mense word nie (I Kor 7:23). ${ }^{11)}$

Hoewel die sakramente in die algemeen in gevangenskap verkeer, erken Luther wanneer hy die doop in die besonder behandel, dat God ten minste hierdie een sakrament in sy kerk bewaar het daarvan dat dit nie besoedel is deur menslike instellinge nie. God het nie geduld dat dit oorweldig word deur winsug en bygelowighede nie omdat $\mathrm{Hy}$ die kindertjies wat nie ontvanklik is vir hebsug en bygeloof, deur die doop wou inwy en deur 'n allereenvoudige geloof in sy woord wou heilig. Vir hulle is die doop nou ook die meeste tot voordeel. As dit aan volwassenes bedien sou word, sou dit nie staande kon bly teen die tirannie van hebsug en bygeloof wat alle goddelike dinge ter neer gewerp het nie. Vleeslike wysheid sou ook hier ongetwyfeld uiteindelik beperkinge en voorbehoude en ander dergelike nette om geld op te vang, versin het, waardeur die water later net so duur as die aflate tans verkoop sou word. ${ }^{12}$ ) Elders het hy daarop gewys dat die belofte in die doop behoue gebly het, maar dat dit by die nagmaal uitgewis is. ${ }^{13}$ )

Nietemin is daar tog 'n paar opsigte waarin ook die doop in 'n mate in gevangeskap verkeer. Die klem wat die kerk op die werke lê ten koste van die geloof, lei daartoe dat die doop vergeet word. Die geloof word vernietig deur die vermeerdering van geloftes, wette en werke en die vryheid van die doop 
word gevange geneem. ${ }^{14)}$ Vanweë die feit dat die teoloë in die middeleeue die sakramente nie reg begryp het nie omdat hulle nie rekening gehou het met die geloof of belofte nie maar slegs vasgehou het aan die teken en gebruik, het hulle almal meegesleur uit die geloof tot die werke en uit die woord na die teken. Daardeur is die sakramente nie slegs gevange geneem nie maar sover dit in hulle mag was, volledig vernietig. ${ }^{15)}$

\section{Die sakramente}

\subsection{Aantal}

Sedert die twaalfde eeu is die sewetal sakramente in die praktyk erken en later offisieel deur die konsilie van Florence in 1439 op sewe vasgestel. Luther het dus bepaald ' $n$ wanklank laat hoor met sy duidelike ontkenning van die sewetal. Hy erken aanvanklik in die geskrif slegs drie, naamlik doop, boete en brood (nagmaal). Hy kwalifiseer homself dadelik deur te stel dat daar egter maar een sakrament is en drie sakramentele tekens. ${ }^{16}$ ) Hy het vroeër die jaar in Februarie 1520 dieselfde standpunt ingeneem in ' $n$ aantal stellinge. ${ }^{17}$ ) Op ' later stadium in die Babiloniese gevangenskap nadat hy die nagmaal, doop en boetedoening behandel het, handhaaf hy nog steeds bogenoemde drie as sakramente. ${ }^{\text {18) }}$

Aan die einde van die geskrif nadat hy alles haarfyn uitgepluis en deurdink het, verander hy egter van gedagte en verklaar dat as ons streng noukeurig wil formuleer (quo fit ut si rigide loqui volumus) - heel konsekwent soos Kamphuis die woorde vertaal ${ }^{19}$ ) - daar slegs twee sakramente in die kerk van God is, naamlik die doop en brood (nagmaal). Sy motivering is dat ons alleen by hierdie twee die teken het wat van Godsweë ingestel is en die belofte van vergifnis van sondes kan sien. ${ }^{20}$ ) Hier het ons 'n mooi voorbeeld van hoe Luther na die Skrif alleen luister, 'n saak kan beredeneer en uiteindelik homself kan korrigeer en dit dan ook openlik stel.

\subsection{Belofte en geloof}

Dit bring ons vervolgens by Luther se sakramentsbeskouing. Volgens hom het God nooit anders met die mens gehandel as deur die woord van belofte nie. Die mens van sy kant weer kan ook nie met God in ' $n$ verhouding staan anders as deur geloof in die woord van sy belofte nie. God gee niks om vir werke nie en het dit ook nie nodig nie. ${ }^{21)}$ Daarom is daar twee dinge nodig, naamlik belofte en geloof. Sonder ' $n$ belofte kan die mens niks glo nie en waar geloof ontbreek, is die belofte nutteloos want deur die geloof word die belofte bevestig en vervul. ${ }^{22}$ Verder is dit ook so dat God gewoonlik in elke belofte van Hom oor die algemeen die een of ander teken daarby voeg waardeur dit getrouer bewaar word en mens kragtiger daartoe opgewek word. So bv. het Hy aan Noag by die belofte dat Hy die aarde nie deur ' $n$ ander sondvloed sou verderwe nie, sy boog in die wolke gegee. Aan Abraham het $\mathrm{Hy}$ by die belofte 
van die erfenis in sy saad, die besnydenis tot 'n seël van die geregtigheid van die geloof gevoeg. ${ }^{231}$

\subsection{Woord en teken}

So is daar in die doop by die woorde van belofte, die teken van onderdompeling in die water. Daaruit bemerk ons dat in elke belofte van God twee dinge voorgestel word, te wete die woord en teken sodat ons die woord as testament verstaan en die teken as sakrament. In die woord is daar meer krag as in die teken, so ook meer krag in die testament as in die sakrament. Mens kan die woord of testament hê en daarvan gebruik maak sonder dat jy die teken of sakrament het. In die verband waar dit oor die nagmaal gaan, haal Luther die woorde van Augustinus aan wat gesê het: glo en jy het geëet. Mens glo egter in niks anders as die woord van God wat die belofte maak nie. En so kan mens daagliks, elke uur, nagmaal hê omdat so dikwels as jy wil, kan jy die woorde van Christus in herinnering roep en jou geloof voed en versterk en dit is dan waarlik 'n geestelike eet en drink. 24)

Ook elders in die geskrif herhaal Luther sy algemene beginsel dat elke sakrament ' $n$ woord van goddelike belofte het waarin elkeen wat die teken opneem, behoort te glo en dat 'n teken alleen nie op sigself 'n sakrament kan wees nie ${ }^{25)}$ Sy slotsom aan die einde van die geskrif is dat in eintlike sin alleen daardie beloftes sakramente is wat met tekens verbonde is. Omdat die ander nie aan tekens verbonde is nie, is hulle blote beloftes. En daarom is daar, soos ons hierbo genoem het, volgens Luther slegs twee sakramente in die kerk van God, naamlik die doop en die nagmaal. ${ }^{26)}$

\subsection{Geloof}

Vanself lei dit ons na Luther se beklemtoning van die geloof in die sakrament. Hy wys daarop dat sakramente nie vervul word terwyl hulle voltrek word nie, maar terwyl hulle geglo word (at sacramenta non implentur dum fiunt, sed dum creduntur). ${ }^{27}$ ) Luther verwyt juis die Roomse Kerk ("ons Babel" noem hy die kerk) dat hy die geloof soseer vernietig het dat hy skaamteloos ontken dat geloof noodsaaklik is in die sakrament. Inteendeel, met antichristelike goddeloosheid het die kerk dit as kettery beskryf as iemand die geloof as noodsaaklik sou handhaaf. ${ }^{28)}$ Mau wys egter daarop dat daar nêrens 'n dergelike uitspraak by teoloë in die kerk voorkom nie. ${ }^{291}$

Wanneer Luther oor die laaste oliesel handel, stel hy die standpunt dat 'n sakrament nie 'n gebed of geloof van die bedienaar vereis nie aangesien selfs ' $n$ goddelose persoon kan doop en wy sonder gebed. ' $n$ Sakrament berus alleen op die belofte en instelling van God en vereis geloof by die persoon wat die sakrament ontvang. ${ }^{30}$ ) Daarom vermaan Luther so ernstig teen die prag en praal van werke en die bedrieëry van menslike tradisies. Die beginpunt is geloof in die sakramente, sonder enige werke en op die geloof volg daar dan wel werke. Luther beskryf die geloof as die voortreflikste en moeilikste "werk" 
want daardeur alleen sal mens gered word selfs al word mens gedwing om al die ander werke te ontbeer. Die geloof is God se werk en nie mense se werk nie. Al die ander werke doen $\mathrm{Hy}$ met ons en deur ons maar hierdie een werk doen $\mathrm{Hy}$ in ons en sonder ons (caetera, nobiscum et per nos operatur, hoc unicum in nobis, et sine nobis operatur). ${ }^{31}$

In die lig van wat hierbo gesê is, is dit skrynend dat die geloof by die sakramente op die agtergrond geraak het, want soos Luther opnuut beklemtoon, is alle sakramente juis ingestel om die geloof te versterk lomnia sacramenta ad fidem alendam sunt instituta). ${ }^{32)}$ Elders sê Luther dat die sakramente bewaar diegene wat in die goddelike belofte glo lat sacramenta servant credentes promissioni divinae). ${ }^{33}$ ) Ten slotte wil ek in die verband daarop wys dat Luther die teken by die sakramente as teken onvergelyklik minder as die saak (inhoud) self beskou. Hy verwyt die kerk juis dat hy die saak self reeds verloor het ten koste van die teken wat veel minder is. ${ }^{34)}$ Die kerk is dus met die mindere (die teken) tevrede terwyl hy die saak (die inhoud) reeds verloor het.

\subsection{Deur God ingestel}

By die instelling van 'n sakrament word daar boweal gevra na 'n woord wat 'n goddelike belofte inhou, waardeur die geloof geoefen word. ${ }^{35}$ ) Daarom meen Luther dat die kerk nie 'n sakrament kan instel nie omdat hy nie die bevoegdheid het om genade te belowe nie want dit kom God alleen toe. ${ }^{36)}$ Ons moet Luther se definisie in gedagte hou naamlik dat ' $n$ sakrament boweal ' $n$ goddelike belofte is. Die kerk het volgens Luther nie die bevoegdheid om nuwe goddelike beloftes van gehade daar te stel nie. Daar is egter diegene wat meen dat omdat die kerk regeer word deur die Heilige Gees, iets wat deur die kerk ingestel is dieselfde gesag het as iets wat deur God ingestel is, maar Luther noem diegene wat so dink niks anders as babbelaars nie. Luther beklemtoon daarteenoor dat die kerk gebore word uit die woord van belofte deur middel van geloof en dat hy deur dié woord gevoed en bewaar word. Dit beteken dat die kerk deur die beloftes van God gekonstitueer word en nie die beloftes van God deur die kerk nie. ${ }^{37}$ ) By die behandeling van die Roomse sakrament van die laaste oliesel verklaar Luther dat dit selfs nie ' $n$ apostel geoorloof is om op sy gesag ' $n$ sakrament in te stel nie, want ' $n$ sakrament is ' $n$ goddelike belofte en 'n teken wat daarmee verbonde is en die instelling daarvan kom Christus alleen toe. ${ }^{38}$ ) Met hierdie standpunt as maatstaf het hy daarom die ander sakramente van die kerk verwerp omdat hulle nie aan die vereistes voldoen nie, naamlik dat hulle deur God (Christus) ingestel is, ' $n$ belofte inhou en dat daar ' $n$ teken daaraan verbonde is.

\section{Die doop}

\subsection{Die belang daarvan}

In sy behandeling van die doop beaam Luther wat pous Eugenius IV en Gabriël 
Biel gesê het naamlik dat die doop die eerste plek beklee en die fondament van alle sakramente is waarsonder daar geen ander verkry kan word nie. ${ }^{39}$ ' Aan die einde van die geskrif vat Luther alles saam deur te sê dat die doop vir die hele lewe geld en dat dit in die plek van al die sakramente voldoende is vir ons hele lewe. Die nagmaal is waarlik die sakrament vir die sterwendes. Die doop is vir die begin en die gang van die hele lewe, die nagmaal vir die einde en die dood. ${ }^{40)}$

Met dit in gedagte kan ons begryp dat Luther dit betreur het dat die doop nie sy regmatige rol in ons lewens speel nie. Volgens hom kon die Satan nie die krag van die doop in klein kindertjies uitwis nie, maar hy het wel die oorhand verkry deurdat hy dit in die geval van volwassenes reggekry het. Daar is naamlik byna niemand wat nog daaraan terugdink dat hy gedoop is en weinig beroem hulle daarin omdat daar soveel ander weë ontdek is waarlangs vergifnis van sonde verkry kan word en mens in die hemel kan kom. ${ }^{41}$ Daarteenoor stel Luther dit dat die mens tot sy dood behoefte daaraan het dat sy geloof gevoed en versterk word deur die voortdurende herinnering aan die belofte wat in die doop aan hom gegee is. ${ }^{42}$ )

Volgens Luther moes die biskoppe die Christene met alle sorgsaamheid na die suiwerheid van die doop terugroep sodat die Christene sou verstaan wie hulle is en hoe hulle behoort op te tree. In der waarheid egter lei die biskoppe die volk so ver as moontlik van die doop af weg en dompel almal in die sondvloed van hul tirannie en bewerk dat die volk van Christus soos die profeet sê, Hom voortdurend vergeet. ${ }^{43}$

\subsection{Doop as belofte}

In ooreenstemming met sy definisie van 'n sakrament as belofte en teken, behandel Luther dan die aspek van die belofte. Die goddelike belofte is te vind in Mk 16:16: wie tot geloof gekom het en gedoop is, sal gered word. Hierdie belofte is onvergelyklik meer te verkies bo werke, geloftes, geestelike ores en wat ookal van menslike kant bedink is. Want daarvan hang ons hele heil af en dit moet so bewaar word sodat ons geloof geoefen word terwyl die gedoopte glad nie daaraan twyfel dat hy gered is nie. As die geloof ontbreek, het die doop geen nut nie maar is dit inderdaad ' $n$ struikelblok want ongeloof stel die goddelike belofte as leuenagtig voor en dit is die grootste van alle sondes.4)

Luther wil dat hierdie saak met ywer aan die volk gebring word, dat die belofte aanhoudend in herinnering geroep word en die doop altyd herhaal word. Soos wat hierdie goddelike belofte wat eenmaal aan ons gemaak is, waar bly tot die dood toe, só moet ook die geloof daarin nooit onderbreek word nie maar tot die dood toe gevoed en versterk word en dit deur steeds gedagtig te bly aan die belofte wat in die doop aan ons gedoen is. ${ }^{45)}$ Hier het ons met 'n pragtige gedagte te doen. Dit is die blywende betekenis van Luther ook vandag waaraan ons gerus aandag kan gee. God het by die doop 'n belofte gedoen en ons moet steeds daaruit lewe. Luther wys dan op die verband tussen doop en berou. Wanneer iemand uit die sonde opstaan of boete 
doen, dan doen hy niks anders as dat hy tot die krag en geloof van die doop terugkeer waarvandaan hy afgeval het. Hy gryp weer die belofte aan wat hy eens afgelê het en wat hy deur in sonde te val, verlaat het. Want die waarheid van die belofte wat eenmaal aan hom gedoen is, bly te alle tye geldig en wanneer ons terugkeer, ontvang dit ons met uitgestrekte hande. ${ }^{46)}$ Reeds in sy preek oor die doop het Luther gesê dat die boetesakrament sy fondament het in die doop omdat alleen diegene wat gedoop is, se sondes vergewe word. So word in die boetesakrament die doop hernu en weer daarna verwys. ${ }^{47}$ Terwyl Luther in sy Sermon slegs twee reëls aan hierdie gedagte wy, het hy dit in die Babiloniese gevangenskap veel breër uitgewerk en presies gesê wat hy bedoel.

Daarom sal dit volgens Luther van groot nut wees as die boeteling boweal aan sy doop herinner word en opnuut met vertroue dink aan die goddelike belofte wat hy verlaat het. Dit moet hy aan die Here bely terwyl hy hom daarin kan verheug dat hy steeds onder die beskutting van die heil gelewe het omdat hy gedoop is. Terselfdertyd sal hy sy goddelose ondankbaarheid verafsku omdat hy van die geloof en die waarheid van sy doop afvallig was. Sy hart sal wonderlik vertroos word deur die gedagte dat die goddelike belofte onmoontlik kan lieg en steeds onverswak geid en deur geen sonde van sy kant verander kan word nie, soos Paulus sê in 2 Tim 2:13: as ons ontrou is, Hy bly getrou, Hy kan Homself nie verloën nie. Hierdie waarheid van God sal hom bewaar sodat as alle dinge in duie stort hierdie belofte indien hy dit glo, hom nie in die steek sal laat nie. Hiermee kan hy die tartende teennstander (sonde) opponeer. Hy het iets wat opgewasse is teen die verskrikking van die dood en die oordeel. Kortom, hy het iets wat 'n troos in alle beproewinge is, naamlik hierdie een waarheid dat God waaragtig is in sy beloftes waarvan hy die seël in die doop ontvang het: as God vir ons is wie kan dan teen ons wees (Rom 8:31). ${ }^{\text {18) }}$

Dit is dus duidelik dat Luther 'n geweldige betekenis toegeken het aan die belofte wat in die doop gegee is. God se belofte is die belofte van lewe en heil en is boweal geldig vir altyd. Uit sy redenering dat die boete ' $n$ nadenke is oor die belofte wat God in die doop gegee het, is dit duidelik waarom Luther aan die einde, wanneer hy al die sakramente behandel het, tot die gevolgtrekking kon kom dat die boete nie ' $n$ sakrament is nie. Dit het nie 'n sigbare teken nie en is nie deur God ingestel nie en is niks anders as die weg en terugkeer na die doop toe nie (viam ac reditum ad baptismum). ${ }^{49}$ ' Wat gebeur eintlik as 'n mens uit sy sonde opstaan en boete doen? Volgens Luther gryp so ' $n$ mens net die belofte aan wat God aan hom in die doop toegesê het. Elke keer dat 'n mens sy sonde besef, beteken dit dat hy opnuut aan sy doop vashou.

Luther illustreer dit met die voorbeeld dat telkens wanneer die Israeliete in berou wou terugkeer tot God, hulle teruggedink het aan hulle uittog uit Egipte. Des te meer behoort ons aan ons uittog uit Egipte terug te dink en deur die herinnering daaraan terug te keer tot God wat ons uitgelei het deur die bad van die wedergeboorte. Ons word aanbeveel om hieraan terug te dink en dit gebeur op die passendste wyse in die sakrament van die brood en wyn en so word die drie sakramente boete, doop en nagmaal terselfdertyd deur dieselfde diens gebruik en die een help die ander. ${ }^{50}$ 
Luther wys daarop dat ' $n$ Christen of ' $n$ gedoopte ' $n$ baie ryk mens is omdat hy nie sy heil deur enige groot sonde ookal kan verloor nie, tensy hy nie meer wil glo nie. Slegs die sonde van ongeloof kan hom veroordeel. As mens se geloof terugkeer of hy bly steun op die goddelike belofte wat in die doop toegesê is, word al die ander sondes in een oomblik verswelg deur dieselfde geloof. Al die dinge wat die mens in sy ywer uitgedink het soos berou en belydenis van sonde, satisfaksies ens. kan hom skielik in die steek laat as hy die goddelike waarheid vergeet en op hierdie dinge sy vertroue gestel het. Die krag van die doop kan egter nie deur die sonde vernietig word nie. ${ }^{51}$,

Ek wil hierdie afdeling afsluit deur ten slotte daarop te wys dat Luther dit beklemtoon dat dit ook ' $n$ troos is dat mens weet dat hy deur God gedoop is. Hy maak ' $n$ onderskeid tussen die menslike bedienaar en God wat die doop ingestel het. In 'n sekere sin doop die mens en doop hy nie. Hy doop omdat hy die daad doen terwyl hy die dopeling onderdompel. Hy doop egter nie in soverre as hy nie op eie gesag die daad verrig nie, maar dit doen in die plek van God. ' $n$ Mens ontvang die doop uit die hand van 'n mens maar op so ' $n$ wyse asof Christus self, ja God self ons met sy eie hande gedoop het. Die mens wat die doophandeling verrig, is dus eintlik die plaasvervanger van God wat in die hemel sit en hom met sy eie hande onderdompel en vergifnis van sondes belowe. Daarom doop die bedienaar nie in sy eie naam nie maar in die Naam van die Vader, die Seun en die Heilige Gees. ${ }^{52}$ )

Hierdie wete dat mens gedoop is nie deur 'n mens nie, maar deur die Drie-enige God self deur middel van ' $n$ mens, is ' $n$ groot vertroosting en kragtige hulpmiddel tot die geloof. ${ }^{53}$ ' Hierdie feit dat die geldigheid van die doop nie afhanklik is van die persoon van die bedienaar nie, illustreer Luther elders deur daarop te wys dat al is die bedienaar goddeloos dit niks afbreuk doen aan die feit dat die persoon gedoop is nie want die krag van die doop rus nie op die geloof van die bedienaar nie maar op die geloof van die dopeling. ${ }^{54}$ )

\subsection{Doop as teken}

Naas die goddelike belofte of testament in die doop, is daar ook die teken of sakrament. Naas die goddelike beloftes is daar ook tekens gegee wat dit afbeeld wat die woorde beteken of soos in dié tyd gesê is, wat die sakrament volgens sy werking beteken. ${ }^{55)}$ Luther wys op die gangbare standpunte: dat daar ' $\mathrm{n}$ verborge geestelike $\mathrm{krag}$ in die woord en water werk; ander meen dat daar geen krag in die sakramente is nie maar dat die genade deur God gegee word; almal stem saam dat die sakramente werksame tekens van die genade is, dat die sakramente van die nuwe verbond groot voordeel het en dat geloof en genade nie vereis word nie maar dit voldoende is solank mens nie ' $n$ hindernis in die weg lê dit wil sê 'n daadwerklike voorneme het om opnuut te sondig nie. Luther beskou dit as ' $n$ dwaling dat gemeen word dat die sakramente van die nuwe verbond verskil van die van die ou verbond wat betref die werksaamheid van die teken. Beide het op gelyke wyse iets aangedui want dit is dieselfde God wat ons deur die doop en nagmaal red en Abel deur ' $n$ of- 
ferande gered het of Noag deur die ark of Abraham deur die besnydenis ens. Dus wat betekenis betref, is daar geen verskil tussen die ou en nuwe verbond nie. Die Mosaïese wetgewing verskil wel hiervan omdat daar geen woord van belofte daaraan verbind is wat geloof vereis nie. ${ }^{56)}$ Die geloof is egter die belangrikste. Die tekens of sakramente wat aan die vroeëre vaders en aan ons gegee is, het ' $n$ woord van belofte daaraan verbonde wat geloof vereis en nie deur werk verkry kan word nie. Daarom is hulle tekens of sakramente van regverdigmaking omdat hulle sakramente van die geloof is en nie van enige werk nie. Hulle hele werksaamheid is deur geloof en nie deur werke nie. Wie in die sakramente glo, volbring hulle selfs al sou hy niks doen nie. Vandaar die gesegde dat nie die sakrament nie, maar die geloof in die sakrament regverdig maak. Abraham en sy nageslag is nie deur die besnydenis geregverdig nie maar dit word ' $n$ seël van die geregtigheid van die geloof genoem. ${ }^{57}$ )

Ons let vervolgens op Luther se siening van geloof in dié verband. Die doop regverdig niemand nie en is op sigself ook van geen nut nie. Die geloof in die woord van belofte waaraan die doop toegevoeg word, maak regverdig en vervul dit wat die doop aandui. Want geloof is die onderdompeling van die ou mens en die te voorskyn kom van die nuwe mens. Let op die woordspeling in die oorspronklike - fides enim est submersio veteris hominis et emersio novi hominis. Daarom sê Luther dat die nuwe sakrament nie van die ou sakramente verskil nie, want hulle het op gelyke wyse goddelike beloftes gegee en dieselfde gees van geloof vereis. ${ }^{58}$ ) Ook elders herhaal Luther sy uitspraak dat die sakramente nie vervul word vir sover hulle voltrek word nie maar wanneer hulle geglo word. ${ }^{59}$ ) Hy kan ook sê dat geloof selfs sonder die sakrament kan red. ${ }^{601}$

\subsection{Betekenis van die doop}

Reeds in sy preek oor die doop het Luther gesê dat die doop beteken 'n sterwe aan die sonde en 'n opstanding in die genade van God. Die ou mens, ontvang en gebore in sonde is verdrink en ' $n$ nuwe mens, gebore in genade, kom voort en staan op. Soos ' $n$ kind uit sy moeder se skoot getrek word en gebore word, so word die mens uit die doop getrek en geestelik gebore. ${ }^{61}$ ' In die Babiloniese gevangenskap werk hy die gedagte breedvoerig uit. Die doop beteken twee dinge: dood en opstanding, dit is volledige en volbragte regverdigmaking. Wanneer die bedienaar ' $n$ kind onderdompel in die water, dui dit op die dood en wanneer hy hom weer uitneem, beteken dit lewe. So verklaar Paulus dit in Rom 6:4. Luther noem hierdie dood en opstanding 'n nuwe skepsel, 'n wedergeboorte en geestelike geboorte. ' $n$ Blote allegoriese verklaring daarvan as van die dood van sonde en lewe van genade, soos baie dit verklaar, wys Luther af want dit gaan om ware dood en opstanding. Die doop is nie 'n teken wat net versin is nie en die sonde sterf ook nie en die genade staan nie volledig op nie totdat die liggaam van sonde, wat ons in hierdie lewe dra, afgebreek word soos Paulus in Rom 6:6 skryf. Want solank ons in die vlees is, roer die begeertes van die vlees en bly dit in beweging. Sodra ons begin glo, begin ons 
terselfdertyd aan hierdie wêreld te sterwe en vir God in die toekomstige lewe te lewe sodat geloof waarlik dood en opstanding mag wees. ${ }^{62}$ )

In sy reeds genoemde preek oor die doop het Luther daarop gewys dat die Griekse woord 'baptismos' en die Latynse woord 'mersio' beteken dat iets heeltemal onder die water is. Volgens hom kom die Duitse woord 'tauff' van die woord 'tieffe' dit wil sê diep onder die water. ${ }^{63 \text { ) }}$

Luther het ook die beeld dat die doop die afwassing van sonde beteken, breedvoerig bespreek. Dit dui natuurlik werklik op die afwassing van sonde maar dit is ' $n$ ligte en swakke teken van wat die doop uitbeeld want dit is eerder ' $n$ simbool van sterwe en weer opstanding. Daarom verkies Luther dat die dopeling heeltemal onder die water gedompel word soos die woord self aandui. Hy meen egter nie dat onderdompeling noodsaaklik is nie maar vind dit mooi dat so ' $n$ volmaakte en volle saak ook ' $n$ vol en volmaakte teken het soos dit ook ongetwyfeld deur Christus ingestel is. Want 'n sondaar behoort nie soseer afgewas te word nie as dat hy moet sterwe sodat hy heeltemal vernuct word tot ' $n$ ander skepsel en sodat hy mag ooreenkom met die dood en opstanding van Christus met wie hy deur die doop saam sterwe en saam opstaan. 'n Mens sou kon sê dat Christus met sy sterwe en opstanding van sy sterflikheid afgewas is maar dit is swakker gestel as wanneer mens sou sê dat Hy heeltemal verander en vernuwe is. So is dit ' $n$ sterker manier om aan te dui dat mens deur die doop geheel en al gesterwe het en opgestaan het tot die ewige lewe as om te sê dat mens se sondes afgewas is. ${ }^{64)}$

Soos wat dit die geval met die belofte was, so is dit ook ten opsigte van die teken, naamlik dat die doop nie 'n saak is wat in 'n oomblik afspeel nie, maar dit loop deur en duur voort. Want hoewel die doophandeling vinnig verby is, duur die saak wat aangedui word tot by die dood, ja selfs die opstanding by die jongste dag. Solank as wat ons lewe, doen ons steeds wat die doop aandui, naamlik sterwe en opstaan. Ons sterwe nie slegs geestelik waardeur ons die sondes en ydelhede van die wêreld afsê nie maar ons begin werklik hierdie liggaamlike lewe verlaat en die toekomstige vasgryp sodat dit 'n werklike en liggaamlike oorgang uit hierdie wêreld na die Vader toe is. ${ }^{65}$ ) Tereg sê Althaus dat volgens Luther alle heiligmaking van die Christen niks anders is as die voltrekking van die doop nie. ${ }^{66}$

So is mens eenkeer op sakramentele wyse gedoop, maar moet hy altyd weer gedoop word deur geloof, moet hy altyd sterwe en altyd weer lewe. Die doop het die hele liggaam verswelg en hom weer teruggegee. Net so moet die doop jou hele lewe met liggaam en siel opneem en weer teruggee op die jongste dag, gekleed met die gewaad van onsterflikheid. So is mens nooit sonder die teken en die saak van die doop self nie. Inteendeel, mens moet altyd meer en meer gedoop word totdat hy op die jongste dag die teken volkome vervul. Wat mens dan in hierdie lewe doen wat betref die doodmaak van die vlees en lewendmaking van die gees, behoort tot die doop. ${ }^{67)}$ Luther vat dit êrens alles saam wanneer hy sê dat mens een taak in die lewe het, naamlik dat hy gedoop word, dit is gedood word en lewe deur geloof in Christus. ${ }^{68)}$ Althaus sê dus tereg dat Luther die doop midde in die lewe van die 
Christen stel. Sy opvatting van die doop is presies die uitdrukking van sy regverdigingsleer. ${ }^{69)}$

Daarom dat Luther dit sien as deel van die mense se gevangenskap wasrin hulle verkeer het dat te midde van soveel ordes, gebruike, sektes, geloftes, inspanninge en werke waarmee Christene hulself besig hou, hulle vergeet van hulle doop of wat hulle in die doop verkry het. Hulle moes eintlik wees soos die klein kindertjies wat gedoop is. Hulle word deur geen ander bemoeienisse en werke in beslag geneem nie en is vry ten opsigte van alle dinge, veilig en behoue kragtens hulle doop alleen. Want sê Luther, ons is ook klein kindertjies, in Christus steeds opnuut gedoop. ${ }^{70}$

As ons alles wat tot dusver gesê is in gedagte hou, kan ons begryp dat Luther daarteen sou waarsku dat mense dink dat die doop later in hul lewe geen betekenis meer sou hê nie. Hy bedoel diegene wat gemeen het dat die genade in mens ingegiet is maar later deur die sonde uitgegiet is en dat mens dan sy toevlug moet neem tot ' $n$ ander weg om na die hemel toe te gaan, asof die doop geheel en al ongeldig gemaak is. Mens kan nie deur boetedoening of deur enige ander weg terugkeer tensy hy na die krag van sy doop terugkeer en opnuut dit doen waartoe hy gedoop is en doen wat sy doop beteken. ${ }^{71}$ )

\section{Die kinderdoop}

$\mathrm{Na}$ bogenoemde uiteensetting is dit asof Luther ons vraag antisipeer, naamlik hoe dit alles rym met die kinderdoop. Hy verwoord self die besware: die kinders begryp niks van die belofte van God en kan ook nie in die doop glo nie. Daarom word of die geloof nie vereis nie of kinders word tevergeefs gedoop. Luther stem in hierdie opsig saam met ander teoloë dat die 'vreemde geloof' die kinders te hulp kom, dit is die geloof van diegene wat die kinders ten doop bring. Hierdie standpunt is gehuldig deur Petrus Lombardus, Tomas van Aquino en Biel, hoewel Biel gesê het dat dit nie die geloof van diegene wat die dopeling bring, is nie maar die geloof van die kerk. ${ }^{22)}$ Luther se redenasie is dat soos die Woord van God magtig is om die hart van ' $n$ goddelose te verander wat nie minder doof en onontvanklik is as die klein kindjie, sò word die kindjie deur die gebed en geloof van die kerk wat hom aanbied, deur die ingegote geloof verander, gereinig en vernuut. Luther wys daarop dat 'n goddelose volwassene terwyl dieselfde kerk vir hom bid en hom aanbring na die sakrament, verander kan word soos die verlamde man waarvan ons in die Evangelie lees (Mk 2:5), deur die geloof van die ander mense wat hom gebring het, genees is. Die sakramente van die nuwe verbond kan genade gee selfs aan diegene wat ' $n$ hindernis in die weg lê. Die geloof en gebed van die kerk sou alles kan oorwin, bv. Paulus is bekeer deur Stefanus. ${ }^{\text {73) }}$

Luther se standpunt ten opsigte van die kinderdoop het verskillende stadiums van ontwikkeling ondergaan. Veral later met die opkoms van die Anabaptiste was hy genoodsaak om hulle argumente te weerlê. Maar reeds in 1522 het hy sy standpunt soos hierbo uiteengesit dat kinders gedoop word op grond van diegene wat hulle ten doop bring, prysgegee, want volgens sy eie 
siening kon niemand salig word deur die geloof van 'n ander nie, maar slegs deur sy eie. Toe het Luther voor die dag gekom met die gedagte van 'n kindergeloof. Hy lei dit af van die reg van die kinderdoop. Die kinders moet gedoop word nie omdat vasstaan dat hulle glo nie, maar omdat die kinderdoop in ooreenstemming is met die Skrif en met die wil van die Here.

Teenoor die Anabaptiste het Luther later toegegee dat die kinderdoop nie uitdruklik in die Skrif bepaal of gebied word nie. Die teendeel is egter ook waar dat daar nie uitdruklik uit die Skrif bewys kan word dat kinders uitgesluit word van die doop nie. Hy wys ook daarop dat die kinderdoop van die ontstaan van die Christendom daar was en onderhou is. Die instandhouding van die kinderdoop deur al die eeue en in alle dele van die Christendom is ook ' $n$ wonder, God se werk. As die kinderdoop vals was dan sou daar meer as 'n duisend jaar geen regte doop gewees het nie en dus ook geen Christenheid nie. ${ }^{74}$,

\section{Ten besluit}

Luther het in sy werk die Babiloniese gevangenskap die Roomse Kerk in sy hart aangeval. Hy verwerp die sewetal sakramente en handhaaf slegs die doop en nagmaal. Hy wys ook daarop dat die sakramente deur God ingestel is en dat dit nie die kerk is wat ' $n$ sakrament daarstel nie. In elke sakrament staan die belofte van God voorop en God het daarby 'n teken daaraan verbind. Hierdie belofte van God moet deur die geloof toegeëien word en kan op geen wyse verdien word of deur enige werk verkry word nie. Die woord van die belofte is ook belangriker as die teken; trouens sonder die teken geld die sakrament nog as dit maar in die geloof aanvaar word.

Die doop verkeer wel in 'n gevangenskap omdat die mense nie meer aan hul doop dink nie omdat daar soveel ander dinge versin is waardeur hulle die heil kan verwerf. Luther het die doop weer in die middel van elke Christen se lewe geplaas. Trouens elke dag, elke uur is dit die een ding waaraan die Christen moet vashou. Dit bied te midde van aanvegtinge en geestelike stryd die krag om te oorwin. Elke sondebesef is ' $n$ terugkeer na die belofte wat in die doop aan die mens gegee is naamlik dat hy gered is. Die doop beteken 'n voortdurende sterwe aan jouself en afsterwe van die wêreld en ' $n$ opstanding in die nuwe lewe. Daarom is die doop nooit afgehandel nie maar duur dit jou hele lewe lank. Om saam te vat: die mens het een taak in sy lewe, naamlik om te lewe uit sy doop, dit wil sê te sterwe en steeds weer op te staan in die nuwe lewe wat God gee.

Dit meen ek, spreek ons almal steeds aan en is die blywende betekenis van Luther se gedagtes.

\section{NOTAS}

1. Kyk bv. S J Botha, "Luther en die sakrament van die doop" in Martin Luther 1483-1546, red. J H Koekemoer, Pretoria 1984, 101-117.

2. A S Wood, Captive to the Word. Martin Luther: Doctor of Sacred Scripture, Paternoster Press 1969, 7. 
3. Kyk my artikel "Die relevansie van Luther se beroep op die Skrif alleen in Afrika-konteks" in New faces of Africa (Essays in honour of Ben (Barend Jacobus) Marais, edited by $\mathrm{J} \mathrm{W}$ Hofmeyr and W S Vorster), Pretoria 1984, 1-13.

4. K Holl, "Die Entstehung von Luthers Kirchenbegriff" in Gesammelte Aufsätze zur Kirchengeschichte, Tübingen 61932, 1:292-293.

5. J Atkinson, Martin Luther and the birth of Protestantism, London rev. ed. 1982, 190.

6. H Boehmer, Der junge Luther, herausg. H Bornkamm, Stuttgart "1951, 262-3.

7. $\mathrm{K} \mathrm{H}$ zur Mühlen, "Luthers Tauflehre und seine Stellung zu den Täufern" in Leben und Werk Martin Luthers von 1526 bis 1546 (Festgabe zu seinem 500 . Geburtstag, herausg. von Helmar Junghans) Göttingen 1983, 1:119-120.

8. WA 6,501,34-36; St 2,1978,18-20. Vir Luther se werke verwys ons na $D$ Martin Luthers Werke, Weimar 1883-, (WA) en Martin Luther. Studienausgabe, herausg. H U Delius, Berlin 1979-, (St).

9. WA 6,535,27-29; St 2,219,3-5.

10. WA 6,521,37-522,2; St 2,203,31-35.

11. WA 6,536,15-17; St 2,219,25-27.

12. WA 6,526,36-527,8; St 2,209,5-16.

13. WA 6,544,10-11; St $2,228,34-36$.

14. WA 6,539,11-16; St 2,223,7-12. Vgl. WA 6,541,15-16; St 2,225,14-15.

15. WA 6,533,25-28; St 2,217,5-8.

16. WA 6,501,33-38; St $2,178,17-21$.

17. WA 6,86,7-8.

18. WA 6,549,16; St 2,234,9.

19. J Kamphuis, "Luther over de boete" in Luther en het gereformeerd protestantisme, red. C Graafland et al., 's-Gravenhage 1982, 203 n. 20.

20. WA 6,572,12-15; St 2,258,17-20.

21. WA 6,516,30-31; St 2, 197,27-30.

22. WA 6,517,8-10; St $2,198,1-3$.

23. WA 6,517,38-518,5; St 2,198,30-35.

24. WA 6,518,12-23; St 2,199,1-11.

25. WA 6,550,25-27; St 2,235, $19-21$.

26. WA 6,572,12-15; St 2,258,16-19.

27. WA 6,533,12-13; St 2,216,21.

28. WA 6,544,14-17; St 2,229,3-5.

29. R Mau, Martin Luther. Studienausgabe, herausg. H U Delius, 2:229 ก. 397.

30. WA 6,570,14-17; St 2,256,21-23.

31. WA 6,530,11-18; St 2,212,17-24.

32. WA 6,529,36; St 2,212,5.

33. WA 6,550,19-20; St 2,235, 14-15.

34. WA 6,504,29-34; St 2, 181,31-182,3.

35. WA 6,550,9-10; St 2,235,4-5.

36. WA 6,561, 19-20; St 2,246,18-19.

37. WA 6,560,31-35; St 2,245,31-35.

38. WA 6,568,12-14; St 2,254,2-4.

39. WA 6,528,17-19; St 2,210,28-30.

40. WA 6,572,23-28; St 2,258,29-33.

41. WA 6, 527,9-12; St 2,209,17-20.

42. WA 6,528,11-13; St 2,210,22-24.

43. WA 6,527,23-28; St 2,209,30-34.

44. WA 6,527,33-528,2; St 2,210,6-14.

45. WA 6,528,8-13; St 2,210,19-24.

46. WA 6,528,13-17; St 2,210,24-28.

47. WA 2,733,29-32; St 1,265,34-36.

48. WA 6,528,20-35; St 2,210,31-211,4.

49. WA 6,572,16-17; St 2,258,21-22. 
50. WA $6,528,36-529,6$; St $2,211,5-13$.

51. WA 6,529,11-24; St $2,211,17-29$.

52. WA 6,530,19-35; St 2,213,1-15.

53. WA 6,531,7-9; St 2,213,23-25.

54. WA 6,531,19-21; St 2,214,1-3. Kyk ook WA 6,526,5; St 2,207,15 en WA 6,570,14-17; St 2,256,21-23.

55. WA 6,531,28-30; St $2,214,10-12$.

56. WA 6,531,31-532,20; St 2,214, 12-215,20.

57. WA 6,532,24-31; St 2,215,23-216,2.

58. WA 6,532,36-533,4; St 2,216,8-12.

59. WA 6,533,12-13; St 2,216,21.

60. WA 6,533,37-534,1; st 2,217,17-18.

61. WA 2,727,30-33; $728,4-7 ;$ St $1,260,9-11 ; 16-18$.

62. WA 6,534,3-17; St 2,217,20-34.

63. WA 2,727,4-15; St 1,259,5-13.

64. WA 6,534,18-30; St 2,217,35-218,7.

65. WA 6,534,31-39; St 2,218,8-15.

66. P Althaus, Die Theologie Martin Luthers, Gütersloh ${ }^{3} 1972,304$.

67. WA 6,535, 10-18; St 2,218,24-32.

68. WA 6,536,1-3; St 2,219,12-14.

69. Althaus, a.W., 305.

70. WA 6,537,35-538,3; St 2,221,1-8.

71. WA 6,535,1-8; St 2,218,16-22.

72. R Mau, Martin Luther. Studienausgabe, herausg. H U Delius, 2:221 n. 346.

73. WA 6,538,4-18; St 2,221,9-222,2.

74. Althaus, a.w., 307-312, Botha, a.w., 115-116. 